\title{
CURRICULUM DEVELOPMENT IN MADRASA: EXPLORATION FROM MUSLIM MINORITY OF WEST PAPUA
}

\author{
Ismail Suardi Wekke \\ State Islamic College (STAIN) of Sorong, Indonesia \\ Jl. Klamono-Sorong, KM. 17, Klablim, Sorong, West Papua \\ Email: iswekke@gmail.com
}

\begin{abstract}
Muslim minority educational development was left behind to explore. The existing researches on the publication are only about Muslim majority. Therefore, it is a need to discover the existence of Muslim minority in the eastern part of Indonesia. This research was conducted in West Papua Province. In-dept interview and nonparticipant observation were conducted to collect data. Focus group discussion was circulated to ensure data triangulation. This study shows that environment neighborhood is one of the factors to consider in curriculum formation. Educational establishment is the breakthrough to fulfill the need of religious education. In addition, the standard to achieve is not only the national average but also there is vision to inaugurate social harmony and cultural situation. Finally, this article concludes that educational management board and teacher panel tried to perceive and hear the sound of milieu. This practice shows a progress of improvement and enhancement in improving relevant curriculum.
\end{abstract}

Keywords: Curriculum, Muslim Minority, Madrasah.

\begin{abstract}
ABSTRAK
Pengembagan pendidikan di wilayah minoritas Muslim tidak mendapatkan perhatian dalam kajian mendalam. Penelitian yang sudah dijalankan hanya menyangkut mayoritas Muslim. Untuk itu, sebuah keperluan untuk menyajikan kondisi minoritas muslim di kawasan timur Indonesia. Penelitian ini dilaksanakan di Provinsi Papua Barat. Wawancara mendalam dan pengamatan tak berpartisipasi dilaksanakan untuk mengumpulkan data. Diskusi terarah diadakan untuk pengecekan triangulasi data. Penelitian ini menunjukean bahwa lingkungan sekitar adalah salah satu faktor yang dipertimbangkan dalam penyusunan kurikulum. Pendirian lembaga pendidikan merupakan terobosan untuk memenubi kebutuban pendidikan keagamaan. Selanjutnya, standar yang bendak dicapai tidak saja mengacu kepada rata-rata nasional tetapi juga visi untuk mengembangkan harmoni sosial dan situasi budaya. Akhirnya, artikel ini menyimpulkan bahwa badan pengurus pendidikan dan dewan guru selalu berusaba untuk menyerap dan mendengarkan suara dari lingkungan sekitar. Praktik. ini menunjukkan sebuah kemajuan untuk pengembangan dan pengayaan dalam membentuk kurikulum yang relevan.
\end{abstract}

Kata Kunci: Kurikulum, Minoritas Muslim, Madrasah. 


\section{INTRODUCTION}

Madrasa education in the framework of national education system of Indonesia has discovered a distinctive strategic place. In the current implementation of formal education, however, it has not been widely implemented by the government, instead the contribution of the community through education movement have found an ideal place, empowering, as well as a real action in strengthening the capacity of individuals. This may be due to the development of community-based education. In Aceh, this is known as meunasah, in Minang it is called surau, while in Java it is called pondoke (Islamic boarding school), all of them have a common purpose to be in the madrassa. This institution then also developed in a larger scale. The development of the Islamic movement has reached to Papua region. Thus, there is also a need to raise the spirit of reaching scientific insights as well as a pray and muamalah deeds that must be coming together with religious knowledge sufficiently.

This opportunity then arose in the need to the establishment of educational institutions that can hold the interest. Islamic Education, organized by non-governmental means; where with the limits of the government, the public instead is present in a position to bring an institution that is able to provide an alternative. Thus, when these institutions have already been in existence, at the same time they would require a blueprint for material and curriculum that will be implemented during the learning process performed. The necessary institutional needs must be implemented in an ongoing basis and précised. Not only are solely to meet the education administrative requirements, but more than that, it is also a much more important aspect in order to achieve the goals and objectives which have been set beforehand. Thus, the phase of determination and curriculum materials that will be a reference within a certain time is important and it needs to be concerned. By that, the continuity of education can be maintained in the case of alumni formation which is relevant to the current environment.

Studies about madrasas, Islamic boarding schools and educational institutions have been widely done by scholars. Yet, the study of Islamic education is limited to see the educational institutions in the context of Muslim majority. Sakai and Isbah (2014, p. 722-746) reported that the transmission of education in the boarding school relies on the diversity. The process of learning is mainly referred to different books and school of thought. Similar findings are also presented by Mas'udi (1985, p. 85) who studied the variety of thinking ways based on fiqh in the learning tradition applied in pondok. Similarly, Azra (2002) also studied the ephitomology of the use of yellow book as the basic foundation of learning. Along with the 
contact and encountering learning ideas, this tradition is also coupled with some learning facilities in higher education levels, as also mentioned in the study of Bafadal (2006).

Considering this matter only, the studies above will lead also to a conclusion that the implementation of Islamic education is limited among the dominant Muslim communities only. While in the other Muslim minority, the education somehow remains to be concerned as well. Such a system of education is held in all levels of education, solely to help family members and also Muslims in the region to access the education. Furthermore, this kind of research on Islamic education in Muslim minority is also widespread in Europe and America. Golosov (2012, p. 93-105) described how Muslims in Russia actively develop education. It is not limited in the form of informal education which remains a struggle in order to move up also at the political level through the legislature. Other studies are also conducted by DahanKalev and Marzel (2012, p. 254-361), researching about the presence of immigrants in France. One of the immigrants' social integration in France is through education. Many Muslim immigrants try to develop the education based on the community ideals without putting aside the existence of the wider socio-political aspect.

A further research was conducted by Nabil Khattab, et. (2012, p. 296309), focuses on the study in Wales. The results of this study explain how ethnicity and religiosity contribute to the continuity of education. By these conditions, there are always some efforts to develop the education in limited scope based on those two identities. Muslims in Wales also enhance their skills to the younger generations in order to expand their employment opportunities. In their local context, education is a course for vocational improvement. A study focusing in Bangladesh is conducted by Bano (2014, p. 911-939). Both studies outline the findings that the Bangladesh educational program has power in social institution and political ability to integrate education and with the demands of western modernity for the community attainment.

These four studies are fully implemented in the context of a national Muslim minority. Unlike the condition of Indonesian, Muslim majority whose research has become a major scientific discourse, in Papua, the themes put in the study are mainly about converts or people who just adopted Islamic religion (Abbas, 2012, p. 498-510), identity (Wekke, 2012a, p. 75-93), entrepreneurship curriculum (Wekke, 2012b, p. 205-226.), and empowerment for community's productivity (Wekke, 2011, p. 23-53), and language education (Wekke, 2014, p. 21-39). These studies, overall, do not specifically focus on curriculum evaluation. Meanwhile, there is a need for studies in order to see how the continuity of curriculum is applied in madrassas. 
Through evaluation, the data will be collected and used as a basis for education planning in this region. Such a concern is also associated with a potential description of education management.

However, this does not describe the existence of Indonesia as a whole. In some regions such as Papua and West Papua, Bali, North Sulawesi, there are Muslim minorities in some specific area trying to build the continuance of education. Thus, this relevance becomes a necessity to carry out the study of Islamic education in West Papua. This study focusing on the evaluation of curriculum development at school also attempts to answer the question "what efforts should the madrasa curriculum development board in West Papua do in order to improve the curriculum based on the conditions of Muslim minorities?".

The two matters highlighted in this research are related to Muslim minorities and pesantren. It is to provide an overview of the continuity of research before heading to the discussion part. One of the most recent studies regarding the Muslim minority was conducted by Suaedy (2012). A study in Pattani, southern Thailand and Mindanao, southern Philippines, shows the strength of local within national identity that grows simultaneously. Civic organizations actively attempts for a peaceful way to achieve internal synergy. At the same time, it tries to distance themselves from the disputing political interests that bring up the idea of separatism and violence. The aspiration is developed within the context of diversity but conducted in substantive ways, such as maintaining the resources in and mandating to have autonomy or self-ruled government. There are two different tendencies that happen on the same side, which is the strengthening of local identity inspired by the spirit of religion and also the presence of global influence in discourse and current movement. Such a paradox precisely brings synergy and peaceful ways loflfe for both ethnicities.

In particular, some studies on Islamic education in minority Muslim were published by McAndrew, Ipgrave and Triki-Yamani (2010, p. 1-4). All the three studies took a focus in Canada and the United States, including the development of a curriculum applied for fulfilling the needs of Muslim community. The results show the interest of public in confirming the identity of Muslims and at the same time also provides an understanding attitude to young people who grow within a completely different attitude from the ones taught in religion. Islamic education will also fortify the students from inappropriate values against the teachings of Islam. Muslim integration within the wider community becomes the main concern of this study. Although the discussion about curriculum is also studied, it is not that comprehensively and only associated to matter of curriculum. Besides, this study includes another integrated element as the focus in the main discussion. 
The concern of researchers and scholars to the issue of Muslim minority is more into viewing the context outside Indonesia, despite the fact that, in its own internal situation, Muslim minorities have been a part of Indonesia. Jannah (2012, p. 443-464) studied about the case of Muslims in Bali. This study concludes that there is a sort of confussion in identity regarding the relationship between Muslims and Hindus in Bali. Social life has always been a contentious issue to be concerned by both parties. Balanced life in accomplishing each respective principle has turned out to be challenge and expectation in social communication. Tolerance, mutual understanding, and adjustment are the keys to establishthe harmony among community members. A variety of life always goes within a dynamic atmosphere, yet people need to attempt for bringing out the aspects like tranquility of life, harmony and unity. Otherwise, balanced life is something impossible to achieve since it is not an instant matter coming straightly from the sky. A form of such misunderstanding among people then will always buttress the continuity of Balinese's public relationship. Within multicultural diversities of identity, there is still social stability. It all starts from the recognition that all people may have different rights regarding what belief they should uphold.

Still in the area of Bali, Jamhari proposes the appropriate type and style of Islamic schools in Bali. The success of boarding schools in Java, also happened in Bali, where pesantren is regarded to be a place for bringing out credible scholars. Fundamental role of pesantren plays a strong role to establish a strong Islamic identity. Having contact and encountering with the wider Hindu community demands the formulation of Islamic education to reinforce their Islamic identity. Although in the minority scale, there are already 114 pesantren. Despite the fact that the number of Muslim demography is relatively smaller than the number of main population in Bali, the number of the education agencies has reached hundreds. This is possibly due to the immigrants from Java, especially the eastern part of Java who considers mosques and pesantren as a very important sojourn place. The mosque can be a means of socialization and meeting-up among immigrants, and represents an opportunity to strengthen social bonds (Jamhari, 2006, p. 171-201).

In Sumatra, Syaukani (2006, p. 55-69) describes the relativity of Muslim minority's position in the middle of the Christian majority. Religious, economic, social and political aspects are the summarized explanations in a research conducted in Brastagi, North Sumatra. Customs factors virtually bring no problems to relationships and interactions. Each party always upholds the beliefs and socio-civic activities independently. The mosque stands adjacent to the church, and the Muslim cemetery is located adjacent to 
the Christian cemetery. This condition is formed by three aspects: the respect for tradition, the purpose of work, and the practice of assimilation. Imam Syaukani also concluded that ethnic Karo always upholds respect and openness to newcomers.

Based on the Muslim community of West Papua, a research conducted by Rais (2012, p. 540-555) came to the conclusion that Kokoda community hasan advantage with the ability to live together without having any conflict. In their daily practices, they always strongly hold the tradition. Behaviors to maintain the group's good reputation, the restriction of being pregnant before marriage, and the prohibition of taking the crops or the property of others, among those practices, the spirit basically comes from their heritage. Local wisdom and religious ideology are formed through religion and the culture is framed after reinterpretation and actualization of contextual meaning. Religious teachings are always maintained as the efforts to hold the predecessor's advice. Motivation and confidence becomes the conception and response for understanding the reality of life. These values or norms are what is always constructed in order to bring positive impact on structuring the society.

Furthermore, the dynamics of pesantren research can also be examined. In a study conducted by Martin van Bruinessen, pesantren is institutionally independent. Historical and cultural journey makes it able to inspire socio-religious developments within the organization. Moreover, pesantren also accommodates the growth of tradition in the community. Through the acculturation process of tradition, boarding community then form phenomenon nuances within its local culture. The Islamic disclosure is adapted to the context and needs of each local community (Bruinessen, 1997, p. 28-30). There are growing behaviors, understanding and cultural diversity. Without denying them all, pesantren actually presents in unique shades. By continuing to appreciate the character of the existing culture, it gives the emphasis on the essence of Islam itself. The disclosure of pesantren in seeing all these phenomena makes it improved and developed in all aspects of life.

A study focusing the case in Papua, precisely of the implementation of educational technology, was conducted by Sain (2013, p. 401-420). This paper describes the development of the use of educational technology for enriching the learning process in schools. There are five aspects simultaneously developed, covering the design, development, utilization, management, and assessment. It shows the diversity in unique and typical integration. It also incorporates the elements of culture. Utilization of educational technology has the potential to help educational process through potential productivity by reducing the burden on teachers, individual 
presentation material, and the opportunity to develop the interests and abilities.

The discussion of research regarding the Muslim minority and pesantren illustrates that the context of this study was conducted within the strategic framework in which the previous researchers did not specifically examine how education explore Islam in Muslim minority region. Also, the study in Papua merely investigates the development of educational technology as a learning source. This research puts a Muslim minority area, exactly West Papua, as a major variable of curriculum development in madrasahs. The aspects of purposes and relevance are the two main grounds for implementing this study.

\section{FINDINGS AND DISCUSSION}

One of the main reference models to evaluate the curriculum is CIPP which was developed by Daniel L. Stuffiebeam. The use of this model is based on some reasons such as comprehensiveness, convenience and practicality. By that, CIPP model is widely and dominantly used in education field. In view Stuffibiem, curriculum evaluation is defined as a process carrying out details to obtain and provide information, which is important for making a decision (Oliva, 1992, p. 481). There are four aspects to investigate as a major component, covering context, input, process and output (Finch and Crunkilton, 1993, p. 268-269). The first two aspects are related to design, while two other aspects are related to the implementation. Aside from that, learning activities as the implementation of the curriculum is regarded as an integral part of the activity.

The other supporting component is teaching materials that become a necessity for achieving the direction and goals. Essentially, the curriculum is regarded as a referential and normative guide for the ministry of education, which will also become the basis of teaching for educators and all components involved in education process. Performance, responsibility, and reality always accompany the complexity of education. As plural educational institutions also require facilitators called teachers, madrasas and boarding school precisely improve and run because of kyai or Islamic scholars as its main teaching component. This is a result of trust given to the kyai or Islamic scholars as the main source of learning, high level of scholar, appropriate level of intellectual and prestigious clerical grades. According to Hiroko Horikoshi, moral excellence of a scholar gives them trust from other people in the sense of appreciation and respect (Horikoshi, 1987, p. 211).

The distribution of Islamic education in Indonesia is somehow related to the firstly evolved cultural integration. The process of making Islamic institutions as a part of Islamic religion is through several stages. In the early 
stages, Islam is presented as a catalyst following the process of assimilation. Regional reaction to this assimilation becomes a firming up process as a part of stabilization, resulting in a dialogue with the local elements of each region. This cultural pattern relationship by Maryam (2012, p. 267) is named with the term "culture of peace". Maryam pointed out that Islam became an inspiration, especially with regards to ethical and moral in life. The conflicts that occur solely because of the lack of communication are conceptual. Moreover, it takes a significant dialogue that will bring harmony and minimize the group's arrogance. Madrasas, then, turn into a strategic forum in this position. Steenbrink (1986, p. 16) has already presented an idea of how pesantren in Indonesia always religious emotional impact resulted from a typical environment. Such religious traditions ultimately move the essence of tradition into a part of ideology.

Despite the fact that education is certainly held in today's process, it is ultimately to prepare for the future. In regards to that, planning becomes a main key for making predictions of the future. Estimation, description and formulation of future are summarized in educational planning presented in a form of curriculum. Through thoroughly completed planning, it would become a projection to assure the expected changes. The process of coordination between educators is important for assuring the integration of all parts. Each unit works with one to another in order to achieve the sustainability linkages of institutions with other principles. This cannot be implemented partially and independently. In line with all those needs, there should be a value of productivity resembling a particular result that has been set through some decisions within a certain time. According to Abduh (1972, p. 117), education is solely an entire development process of the nature of learners, especially with respect to reason and religion. The opportunity to maximize this nature will be able to cultivate the power of rational thinking. As for the nature of religion, important pillars of goodness or good deeds will be embedded in self-learners, which may bring impact on those learners' entire life.

The dynamics of the era and the needs of society where education was implemented becomes a main factor for improving education. In education management of pesantren, the curriculum is not regarded as a standard form. However, Lukens-Bull (2004, p. 64) describes the boarding school curriculum in four forms: (1) religious education, (2) the experience and moral education, (3) schools and public education, (4) the skills and courses. Standardization of these four groups occurs due to the development of curriculum, expectations and demands of society to the boarding school. Azra (1999, p. 95-96) argues that this is solely because boarding ability to survive and change (continuity and change). The commitment to Islam and 
moral education which is oriented on yellow book becomes endurance in pondok. While the process of adaptation lies in people's willingness to respond the demands and community development. When the formalization of education is required, pesantren comes in forms of boarding schools and madrasahs system. Meanwhile, educational boarding school is integrated with a variety of courses and training for skills formation when the students need further vocational abilities.

In fact, along with the introduction of education modernization in the Islamic world, not many traditional educational institutions are able to survive. Among those who are still able to keep it running, it is the pesantren with any forms of development following the improvement of era. Some considerations on cultural values, environment, and local communities can make a typical Indonesian pesantren as institutions. The process of renewing it comes internally back from the pesantren. The establishment of pesantren is a part of action valuing and interpreting the religion as a symbol of needs in society. Based on these studies, it is pertinent to make madrasah as a topic of study for exploring the institutional position related to the curriculum and environment.

The curriculum was basically designed for mastering the whole religious teachings. However, those teachings are imposible to be taught within a limited time. A strategy is needed in order to accomplish those needs, by aiming the process of learning to teach science, to understand, and to reconstruct tools for deepening the understanding of Islamic religion. The main aspect that the students should master is Arabic language and other related knowledge. It is intended as an initial step for understanding Qur'an and Sunnah that has become the rule of God as embodied in Arabic language. By using a very practical example, the understanding of Arabic language is helpful for understanding the content of the prayer reading. Furthermore, determination and belief in religion will be more stable and firm if the belief originally and directly comes from the main credible source. Misapprehention of religious teachings and advice will end up having chaos and indecision in one's life.

Principles of curriculum development are carefully arranged. Possible mistakes laying in the foundation of curriculum development will result in failed construction of curriculum. More to say, that will also become the main cause of failure in learning process. By that, the changes and innovations of curriculum are designed and arranged in an integrated manner. In addition to the feasibility of knowledge and of understanding in this process, it is necessary to have adequate knowledge about the environment in order to ensure whether the teaching and learning can perfectly be applied. Observation and data collection prior to the 
involvement of basic curriculum changes have to be initially put under consideratuin, in order to achieve the already defined outcomes for the future. Yet, this is not the only factor that determines the success itself. The determination of curriculum structure that is optimally arranged, at least, already has a good foundation for continuingthe process of education to the next stage.

Considering the above case, the ability to speak Arabic becomes a major concern in the development of curriculum. Some subjects are started from the mastery of Arabic competence. Upon the completion of the Arabic language learning materials, the subjects will be easier to understand and explore. Thus, Arabic language is used as the basis for the establishment of further competence. However, linguistic competence to be developed does not lie on the mastery of grammar and grammatical context. Mastery of this language is aimed more to be communicative and also applicable in contextual studies. Understanding Turath book remains important, but this is only into an introduction and also encouraging the competencce to conduct independent studies.

In madrasa context, the educational environment is to provide an opportunity for the students to directly experience the process of worship, in which thes experience will become the main learning instrument for the students. They are simply supposed to sit and memorize all the rituals, but, further than that, it would be better for them to experience the interaction, and the spiritual process. Besides, those processes will help them to naturally understand the existing environment as well as to encourage them to explore deeper about the knowledge by consulting to their teachers and advisors in their pondok. Learning outcomes will then be presented in their daily behavior, sustainability, overall activities, and also attitude. In terms of cognitive aspect, learning by experience will be a factor to make adjustments towards the possible changes. At the happening time of the adjustment process, the adaptation and response will become a conscious effort in shaping automatic or responsive attitudes.

Environment is not a mere classroom bordered by the walls. It involves peer, teacher, educators and other various madrasas elements, which provides multiples roles in learning process. Some patterns developed in the environment include student interaction with their peers, their teachers, and their school environment, which all will give them opportunity to posture different attitudes. The process of socialization itself becomes a golden opportunity to understand any possible different perspective. Processing meanings, environmental communication, and behavior changes will become a means of learning, especially related to religious attitude which is not possible to do by force or assertion. 
Experiential learning also requires practices. This is the ground of why the environment around madrassa should be properly arranged in support of the learning process. Environment, in this case, is simply the media. Other than that, the teachers will also take roles as a catalyst of the learning process through environment. The teachers help the students to always understand the running processes so that the structure and meaning of knowledge that the students obtain will be constructed as a meaningful experience. Behavior, practices and experience of environment will be a system that can be reflected as a part of the learning activity. The environment will also cover a particular context beneficial for the discussion during learning process in the classroom. Providing such an environment will also be a lively practice. Learning in the classroom covers the process of understanding, which is then continued in the environmental learning as a form of practice. The association between the classrom and the environment occurs in a regular pattern that will expedite the students' learning process.

In overall view, the process of learning will not complete and reach the actualization of life if it is only bordered within the environment of learning. There should be some efforts in order to bring the learning environment closer to the reality of the students' everyday life. The opportunity to apply the mastered skills will also be in a real step. If the students do not apply the lessons and knowledge that they obtain from class and practice in the school environment, the skills and knowledge will be lost and forgotten. Active involvement will turn the experience into knowledge. Furthermore, knowledge is understood and learned in order to acquire wisdom and appropriate action. The final stage of such action is indeed indispensable to be applied as a whole learning process in order to form everyday's meaningful and inherent behavior.

The curriculum of madrasas is a complete system, which cannot be separated from the other learning components. The impact of learning is not only assessed in form of number and written in a report at the end of the semester. It must also bring impacts in which the students can apply the knowledge they have mastered. The transfer of knowledge from teachers to the students is supposed to be conducted with the principles of independence. Communication in the process of teaching and learning should be able to notice that the students have owned their prior competence and capacity. The students already possessed certain abilities, which just need to be seen in general, which will also allow each student to differently access the learning method. At this point, the development of learning is to provide students the opportunity to acquire the meaning of learning in advanced levels. 


\section{Entrepreneurship in Islamic Education}

The managers and supervisors of Pesantren Rodlotul Khuffadz, Aimas, since the beginning, have seen the unskillfulness of the students graduated from madrassa and pesantren. Grounding on that case, during the establishment of Pesantren Rodlotul Khuffadz, Kyai Yasin has prepared and trained the students with the skills of farming and raising animals, including some further skills such as raising fish, both fishes to eat and to be the ornament. The region of pesantren located in the area of agriculture carries supporting alternative. The students in madrassas ibtidaiyah (similar level to junior high school) and madrassas tsanawiyah(similar level to senior high school) are guided by the farmers living around the pesantren to manage vegetable garden, chicken coop and ducks, tilapia and catfish ponds, and ornamental and aquarium fish. This special program supports the continuity of education as it is also supported by some relevant agencies such as Department of Fisheries, Department of Agriculture, and Department of Education.

Although pesantren manages the madrassas, the sustainability of the program and the viability of continuing the education should get proper attention and support from the Department of Education. The students work in groups to manage the land prepared by the pesantren. They learn and practice the skills they acquire from the farmers and agricultural instructors. Initially, the pesantren only has one hectare, but due to the fruitful results of farms, it is finally able to widen the land by purchasing some of the adjacent lands. It is also in line with the improvement of madrassa which initially just built up madrassa ibtidaiyah, and in 2011 it began to open madrassas tsanawiyah. Because of the issues of ability, time and effort, the students are not the main worker in the management of these lands. The advisors of pesantren remain as the main organizer, while the students are only given the opportunity to learn and to directly practice the activities they have previously discussed in the classroom.

Aimas' environmental condition completed with the potential of agricultural land is seen as an opportunity to associate the education with the needs of people living around. The farmers who grow crops are originally the transmigrant coming since Soeharto's new order regime. There are some abandoned lands aside from the supply of food needs coming from outside the region. Along with the development of pesantren Rodlotul Khuffadz, the education managers not only involve the students in the learning process but also provide an opportunity for the community to get together with the students, teachers, and instructors in order to manage the agricultural land. By using such a pattern, Pesantren Rodlotul Khuffadz gets some help to manage a thousand ducks. Additional activities to manage chicken and duck 
farms allow the local residents to get some skills of raising animals. Furthermore, the duck and chicken coops are managed by a small group, with the division of feeding and harvesting the eggs. The residents ask for the students' help and willingness to contribute their work for these farms.

A pattern to develop in this study is related to the integration and involvement of people. As what Kyai Yasin delivered, without combining the skills with religious education, the public perception that the madrasa merely takes care of Hereafter affairs is true. While taking care of the hereafter skills, materialism and skills learned in daily life is used as a tool to accomplish the affairs of afterlife. The options of farming, fishing and agriculture refer to the condition of West Papua, while the policies to involve the local community in running the programs of pesantren are intended to be an effort to spread the entrepreneurial spirit to the people around, as well as to invite the community to participate in maintaining the continuity of pesantren. At the same time, the people there can also become teachers and caregivers of the students. Due to the unbalaced ratio betweenthe teachers and the students, the presence of the residents will help in the role of instructors.

The educational system managed by pesantren Rodlotul Khuffadz suggests that innovation is the key of educational continuity. Adding some programs close to everyday society will provide adequate involvement and support to actuate the existing potential. Pesantren is always in line with the demands of society. The ability to read such a demand is precisely the excellence of pesantren which also suggests that pesantren is always close to the environment. Limited means of education is indeed not an obstacle to maintain the continuity of education. The media of learning is adapted from land of pesantren, while the shortage of teachers is solved by asking the local people to be the complement of education process.

\section{Sharing, Tolerance, and Harmony}

Education system managed by Islamic organization such as Muhammadiyah, Nahdlatul Ulama, and Islamic Education Foundation (YAPIS) accepts not only Islam students but also students from other religions. This policy is executed in order to provide the widest possible access to education for every individual regardless their religious background. The students are also provided with an opportunity to take on the process of education and also other facilities, such as scholarships and mentoring for extra-curricular activities. Educational institutions become a vehicle for improving the attitude and also the reality of diversity in society. The difference, classification and being different are a form of unlimited facts in everyday life. In pesantren, therefore, it is well recognized, appreciated and also given a place to stay well, not to deny and negate. 
The students are given the opportunity to celebrate a religious commemoration in groups, while the different groups give an appreciation of other celebrations, and even help in the preparation of the event. During the performance of event, these different groups even will contribute to the activities. The school even provides an opportunity for each student to express their religious beliefs, to confirm their piety, and to have active learning. The given services are also to provide freedom for individuals, selfdetermination, and self growth. This is reflected in the celebration of Idul Fitri where non-Muslim students also participate in helping to clear the field that will be used in the Eid prayer. While in the celebration of Christmas, Muslim students also help prepare the food given to the invited guests. Among the guests, there are some Muslims as well. The committees of those religious events are jointly managed. Cooperation and mutual understanding are regarded as a real experience without the need to question the beliefs of each person.

The pattern of this relationship develops because of the element of kinship that becomes a part of life in Papua and West Papua. The term of "Sapu Sodara" is an abbreviation of "saya punya saudara" (I have brothers/sisters), indicating the bond of brotherhood that serve as the foundation of life in the pesantren. This principle is also likely to make communities of people in Papua and West Papua willing to accept any differences and religious beliefs, based on the status of humanity. By that, people there still retain this conception. Although there are differences of religion along with the development of Islam and Christianity, keeping the fraternityis believed to be an effort to preserve the heritage. For example, four of the five kings in Kokoda tribe have accepted Islam as one of religiousbeliefs, while the other one accepts Christianity. This kind of differences then comes in generations, resulting on the understanding that different religion is never a problem for it precisely has to be a bond of brotherhood that must be maintained for ever.

Within the attitudes of kinship, solidarity is formed. It also becomes an adhesive which brings neither conflicts nor gaps caused by the religious factor. Each gives freedom to others for carrying out religious practices without being disturbed by their behavior. Instead, in some internal groups, the above aspect is supposed to maintain the identity for building up the interfaith cooperation. If suspicion and rivalry appears, harmony is one thing that has to be attempted in order to prevent any possible conflicts. Precisely, religious differences are supposed to be used as an adhesive and a chance to share with each other. 


\section{Learning from Everyday Situation}

The strength of studying in madrasas as well as inviting the students to observe everyday situations are arranged as an early stage in the learning process. Using a practical environment close to the student's life makes the teacher easier to explain the situations. Likewise, the same process is also helpful to determine the outcomes of educational process, considering that the students will, anyway, return to the life they have been living in. Isolaiting the contextual conditions will somehow complicate the students' learning process as well as turn the materials taught to be meaningless. Such convenience will be the basis for students to learn in the next stage. Once they get aware of the prime keys of life, they will be able to understand the processes that occur around them. Integrated Islamic Elementary School (SDIT) al-Izzah, Malanu and Ghuraba, Aimas, applies the concept to make use of the existing organ for the learning process, and to apply the concepts that the students have learned through their daily reality. Proximity and experiences that shape the memory becomes a basis to improve the mental power. In the next turn, this will also strengthen the eagerness to learn.

The schools were established by young people who have just completed their college education. After getting a waqf from their parents and from the community leaders, they together build up some madrassas equipped with additional facilites. National education curriculum has been adopted as the main learning material, and then added with the competence to read and write the Koran, to memorizeshort verses, to understand the basic Arabic language, to learn English, and to do some sportsselected by the students. Talent search is also conducted since the beginning, when students are in the second grade. Itis also a part of involving parents in the educational processed. Periodically, the parents are invited to seethe teachers. Then, the teachers will askfor the parents' willingness to support and to accompany the students during their learning process. Communication amongst the principal, parents, and teachers will determine whether an additional learning activity is needed to be implemented at schools.

Learning program comes together with habits. Everyday, the students will have to read the Koran before starting to study. This habit is applied continually as follows some bases such as prayers, optional fasting, sick people visit, and orphanage visit. Hopefully, through these activities, the students will learn to build awareness and consciousness. In some cases, the teacher's explanations, discussions and readings also will not give a full picture of knwoedge without directly performing them in form of activities. Thus, it will also be easier interpreted understanding students. The association and the attitude of students in this program are to foster the 
students' tendencies. Finally, the internally arisen consciousness will shape up a manner influencing the attitudes.

Religious consciousness does not simply occur. It must go through the stages and process of awareness to actualizeasort of formation. This opportunity will encourage an understanding, appreciation, and trust, built on the bases of behavior and attitudes.

\section{CONCLUSION}

This paper describes how madrassas use the environment as a factor of curriculum development. Some studies about reliogion were conducted continuously by using the principles of relevance and contextual environment. It is then concluded that the existence of an educational institution is linked to the surrounding environment. The minority of Muslims in madrassas in West Papua does not weaken the Muslim community in managing the process of education. This precisely becomes a factor confirming that the continuity of education is managed by the principles of adequate governance of education.

One of the aspects to concern is the development of the curriculum at schools. Based on the educational institutions being studied, it shows that the educational administrators, teachers and educational staff have made the curriculum as the initial determination. In developing the curriculum, those people pay attention to the national standards and also conduct a study on the socio-cultural conditions of the community. Then, the curriculum is applied in a variety of approaches. One approach that is used as a common reference is the need for innovation in teaching and learning process. It is intended to provide a basis of learning material enrichment, and also to overcome the lack of available instructional media. Based on those goals, the teachers are always demanded to teach by using a variety of learning media.

Finally, this study only examines some of the madrasas in Sorong City and Sorong Regency. Due to these limitations, the results cannot be completely generalized to the entire region of West Papua until it will be found further categories and findings from the expanded study in similar topic to this research. Also, through the limited scope, this study may be able to explain the phenomenon of Muslim minority around madrasas in West Papua. Yet, it needs further data and discussion of the madrasas, which can also cover the phemonenon happening in other districts so that can provide broader conclusion from wider objects of the study.

This study shows the dynamics of the curriculum development of at schools with Muslim minority in their cultural condition. In response to the development of education, madrassa tries to adjust this condition to the education process in order to form an education-based entrepreneurship. As 
in Pesantren Roudhotul Khuffadz, Aimas, education is managed by providing complete entrepreneurial and technical skills for the students after having formal education. This finding is pertinent with a research conducted by Marius Pretorius, Gideon Neiman and Jurie van Vuuren in view of entrepreneurship education as the model. By integrating the education and entrepreneurship, this process is aimed to build up business and innovation for facilitating the progress of economic. This study also examines, in particular, the role of education in relation to the existence of institutions in the region of community development (Pretorius, Nieman, and Vuuren, 2005, p. 413-427).

In relation to the Muslim minority, the existence of madrasa is regarded as a part of scholarly activity for disseminating scientific viewpoints guided by the spirit of Islam. This is different from the scientific Islamization initiated by al-Faruqi (1984, p. 35), mentioning that Madrasas and pesantrensolely cover Islamic insight into the idea of education, religious principles, environmental requirements, and integration components. Awareness to establish educational institutions is started by strengthening the identity. As a minor community, there has always been an attempt to maintain a religious identity which is different from the other groups. Similar conclusion is also stated in the study of Skinner (1963, p. 97) who saw the Chinese minority within the other large groups in Indonesia. This awareness comes with the basic human needs, exactly in recognition and social relationships (Muluk, 2005, p. 5).

This study shows that the curriculum developed by the Muslim minority is madrasa is always related sociological bases, such as the current practice, the needs of the community, and the environmental conditions daily. All of these also summarize the aspects of peaceful life and diversity. These bases are also used in for positioning the madrasas in the middle of heterogeneity amongst the communities. The same results are also obtained from the study conducted by Abdullah (2011, p. 249) Assalaam, Surakarta. However, this research only assessed the diversity ofIslamic perspectives in Solo without involving the elements outside the Muslim community. On the other hand, the terminology of heterogeneity mentioning in this paper also includes non-Muslim community as a contributing factor. Each aspect somehow has an existing inclusive vision in order to build a harmonious social relationship with the environment. It also shows that there is a process and a product that is always used in curriculum-planning. Such a model is always open and able to encourage their participation to make agreement.

The results of this study, again, show that madrassas are always open towards improvement and willing to participate in community change. However, this is not a new finding as a study previously conducted by 
Damopolii (2011, p. 307) IMMIM has adopted institutional boarding school in Java. Just by looking at the condition of society in Bugis and Makassar in South Sulawesi, DPP IMMIM actually has made a breakthrough by not placing scholars as an early element, but it actually takes the management to empower the management of education. So is the initial research on pesantren conducted by Ziemek (1986, p. 179), especially in regards to social change. Moreover, pesantren is further described as a community development center, after looking at the argument that view pesantrenas a starting base and rationale for self-organization, and by the residents, it is applied in response to existing conditions. In line with Geaves' research (2015, p. 64-82), United Kingdom educational institution establishes pedagogy as the main acivity. Furthermore, relevance is the main factor to consider in maintaining the educational program.

Including a research conducted by Marhumah (2008, p. 183-185), pesantren leaders have proved to have a significant share in the social construct of gender roles in the traditional boarding schools. In fact, a strong tradition in holding the ideals from its predecessor could have been done by using a transmission capacity carried out by the pesantren. As a source of the strongest influences that may affect the way of people's thinking, the Kyai will be dynamist in learning and institutional structure of madrasah. The same descriptionis simultaneously presented by Rahardjo (1995, p. 3), mentioning that no matter how large the number of pesantren that continually grows, it has a function in the process of society development. At least, it becomes the center of spiritual life and a life-oriented world viewing on the issues hereafter and worship. All of these is started because pesantren is constantly treated by the desire to become the source of reformation process that has always become the pulse of life itself (Wekke and Busri, 2011, p. 112). Finally, this study also concludes that the Muslim community makes madrassa as a major necessity. One foremost solution is to unite Muslims through the establishment of educational institutions.

\section{BIBLIOGRAPHY}

Abbas., (2012). Komunitas Muallaf yang Terabaikan dalam Pelayanan Keagamaan Klalin, Sorong: Jurnal Pemikiran Islam Al-Fikr, Vol. 16, No. 3, September-December, 498-510.

Abduh, Muhammad., (1972). al-Madaris al-Tajhiziyatwa al-Madaris al-Aliyat. In Imarah (eds.) al-A'mal al-Kamil li al-Imam Mubammad Abduh. Vol. III. Beirut: al-Muassasah al-Arabiyah li al-Dirasahwa al-Nashr.

Al-Faruqi, Ismail Raji., (1984). Islamisasi Ilmu Pengetahuan.Translation Anas Wahyuddin. Bandung: Pustaka. 
Aly, Abdullah., (2011). Pendidikan Islam Multikultural di Pesantren.Yogyakarta: PustakaPelajar.

Azra, Azyumardi., (1999). Pendidikan Islam Tradisidan Modernisasi Milineum Baru. Jakarta: Logos.

Azra, Azyumardi., (2002). KitabKuning: Tradisi dan Epistemologi Keilmuan Islam di Indonesia. In AzyumardiAzra (ed.). Pendidikan Islam: Tradisidan Modernisasi Menuju Milenium Baru. Jakarta: Logos.

Bafadal, Fadhal A. R. and Syatibi, M., (2006). Pergeseran Literatur Pondok Pesantren Salafiyah di Indonesia. Jakarta: Balitbang dan Diklat Departemen Agama.

Bano, Masooda., (2014). Madrasa Reforms and Islamic Modernism in Bangladesh: Modern Asian Studies, Vol. 48, No. 4, July, 911-939.

Damopolii, Muljono., (2011). Pesantren Modern IMMIM Pencetak Muslim Moderen. Jakarta: Rajawali Pers.

Finch, Curtin R. and Crunkilton, John R., (1993). Curriculum Development. Boston dan London: Allyn and Bacon.

Geaves, Ron., (2015). An Exploration of The Viability of Partnership Between Dar Al-Ulum and Higher Education Institutions in North West England Focusing Upon Pedagogy and Relevance: British Journal Of Religious Education, Vol. 37, No. 1, 64-82.

Golosov, Grigori V., (2012). The Representation of Ethnic Muslims in Russia's Regional Legislative Assemblies: Journal of Eurasian Studies, Vol. 3, 93-105.

Horikoshi, Hiroko., (1987). Kiaidan Perubahan Sosial. Jakarta: P3M.

Jamhari., (2006). Pesantren di Bali: Pendidikan Islam di Daerah Minoritas. In Mencetak. Muslim Modern, Jajat Burhanuddin and Dina Afrianty (eds.). Jakarta: RajaGrafindoPersada.

Jannah, Siti Raudhatul., (2012). Kegalauan Identitas: Dilema Hubungan Muslimin dan Hindu di Bali: Jurnal Studi Keislaman Ulumuna, Vol. 16, No. 2, December, 443-464.

Kalev, Henriette Dahanand Marzel, Shoshana-Rose., (2012). Liberte, Egalite, Islamite: Coping Strategies of Female Immigrants from the Maghreb in France: Women's Studies International Forum, Vol. 35, 254-361.

Khattab, Nabil; Johnston, Ron; Sirkeci, Ibrahim; and Modood, Tariq., (2012). Returns on Education Amongst Men in England and Wales: The Impact of Residential Segrergation and Ethno-religious Background: Research in Social Stratification and Mobility, Vol. 30, 2012, 296-309.

Lukens-Bull, Ronald Alan., (2004). Jihad Ala Pesantren di Mata Antropolog Amerika. Yogyakarta: Gama Media.

Marhumah, Ema. (2008). Konstruksi Sosial Gender di Pesantren.Yogyakarta: LKiS. 
Maryam, Siti., (2012). Damai dalam Budaya. Jakarta: Badan Litbang dan Diklat Kementerian Agama RI.

Mas'udi, Masdar F., (1985). Mengenal Pemikiran Kitab Kuning. In M. Dawam Rahardjo (eds.). Pergulatan Dunia Pesantren: Membangun dari Bawah. Jakarta: P3M.

McAndrew, Marie; Ipgrave, Julia; and Triki-Yamani, Amina., (2010). The Education of Minority Muslim Students: Comparative Perspective: International Migration and Integration, 11, 1-4.

Muluk, Hamdi., (2005). Psikologi Mayoritas Muslim, Multiloyalitas Perilaku Politik dan Isu-isu Radikalisme Islam di Indonesia. Paper presented in Workshop dan Seminar Nasional Psikologi Mayoritas-Minoritas. Faculty of Psychologhy UIN SyarifHidayatullah Jakarta, 3 October.

Oliva, Feter F., (1992). Developing the Curriculum. New York: HarperCollins Publishers Inc.

Pretorius, Marius; Nieman, Gideon; and Van Vuuren, Jurie. (2005). Critical Evaluation of Two Models for Entrepreneurial Education: International Journal of Educational Management, Vol. 19, No. 5, 413-427.

Rahardjo, Dawam., (1995). Pesantren dan Pembaharuan. Fifth Edition. Jakarta: LP3ES.

Rais, Muhammad., (2012). Dialektika Faham dan Praktik Keagamaan Komunitas Kokoda-Papua dalam Budaya dan Kearifan Lokal: Jurnal Pemikiran Islam Al-Fikr, Vol. 16, No 3, September-December, 540-555.

Sain, M. Dahlan., (2013). Hakekat Pengembangan Teknologi Pendidikan: Jurnal Kependidikan dan Hukum Islam Jabal Hikmah, Vol. 6, No. 11, January, 401-420.

Sakai, Minako; and Isbah, M. Falikul., (2014). Limits to Religious Diversity Practice in Indonesia Case Studies from Religious Philanthropic Institutions and Traditional Islamic Schools: Asian Journal of Social Science, Vol. 42, No. 6, 722-746.

Skinner, G. William., (1963). The Chinese Minority. In Indonesia, Ruth T. MacVey (eds.). New Haven: Yale University South Asia Studies.

Steenbrink, Karel A., (1986). Pesantren, Madrasah Sekolah, Pendidikan Islam dalam Kurun Moderen. Jakarta: LP3ES.

Suaedy, Ahmad., (2012). Dinamika Minoritas Muslim Mencari Jalan Damai. Jakarta: Badan Litbang dan Diklat Kementerian Agama RI dan The Wahid Institute.

Syaukani, Imam., (2006). RelativitasPosisiMinoritas Muslim di Tengah Mayoritas Kristen: Jurnal Penelitian dan Kajian Keagamaan Dialog, Vol. XXIX, No. 62, December, 55-69.

Van Bruinessen, Martin., (1997). NU: Tradisi, Relasi-relasiKuasa, dan Pencarian Wacana Baru. Yogyakarta: LKiS. 
Wekke, Ismail Suardi dan Busri, Mat., (2011). Pembaruan Pendidikan Islam Studi atas Pemikiran Imam Zarkasyi. Sorong: Pustaka Rafana.

Wekke, Ismail Suardi. (2011). Pendidikan Islam dan Pemberdayaan Masyarakat (Tinjauan Pendidikan Vokasional Pesantren Roudhatul Khuffadz Sorong): Jurnal Kajian Islam Interdisipliner Hermenia, Vol. 10, No. 1, December, 23-53.

Wekke, Ismail Suardi., (2012a). Pembelajaran dan Identitas Muslim Minoritas: Jurnal Ilmu Pendidikan al-Rabwah, Vol. VI, No. 2, November, 75-93.

Wekke, Ismail Suardi., (2012b). Pesantren dan Pengembangan Kurikulum Kewirausahaan: Kajian Pesantren Roudhatul Khuffadz Sorong Papua Barat: Jurnal Penelitian Sosial Keagamaan Inferensi, Vol. 6, No. 2, December, 205-226.

Wekke, Ismail Suardi., (2014). Tradisi Pesantren Dalam Konstruksi Kurikulum Bahasa Arab di Lembaga Pendidikan Minoritas Muslim Papua Barat: Karsa, Vol. 22, No. 1, June, 21-39.

Ziemek, Manfred., (1986). Pesantren dalam Perubahan Sosial. Jakarta: P3M. 